\title{
Student Self-Evaluation and Autonomy Development in EFL Learning
}

\author{
Henry Sevilla Morales \\ Universidad de Costa Rica - Universidad Nacional, Costa Rica \\ Roy Gamboa Mena \\ Universidad de Costa Rica
}

\begin{abstract}
This paper examines the connection between student self-evaluation strategies and autonomy development in the English as a Foreign Language (EFL) classroom. To this end, 18 students enrolled in a phonetics class participated in a constructivist-based action research plan. Using different autonomy-oriented instruments, students set their learning goals and self-assessment strategies to foster learner autonomy and evaluated their learning experiences at the end of the semester. The study adopted a triangulation mixed methods design, where quantitative results were used concurrently with the qualitative data. Findings suggest clear-cut connections between self-evaluation strategies and the development of learner autonomy in the context of EFL.
\end{abstract}

Key Words: self-evaluation, learner autonomy, constructivism, action research, EFL

\section{Resumen}

El presente estudio explora la relación entre la autoevaluación del estudiante y el desarrollo de la autonomía en el aula de inglés como lengua extranjera (EFL, por sus siglas en inglés). Para este fin, 18 estudiantes matriculados en un curso de fonética del idioma inglés participaron en un proyecto de investigación-acción, el cual se basó en los principios de la pedagogía constructivista. Por medio de distintos instrumentos para potenciar la autonomía, los estudiantes se fijaron metas de aprendizaje y estrategias de autoevaluación, y evaluaron la experiencia de llevar un plan semanal y un diario mediante una lista de cotejo. Se utilizó el 
diseño de métodos mixtos de triangulación, en el cual se interpolaron datos cuantitativodescriptivos con información cuantitativo-explicativa. Los hallazgos revelan una clara relación entre las estrategias de autoevaluación como la aquí implementada y el desarrollo de la autonomía en el aprendizaje en EFL. Asimismo, estos sugieren implicaciones tanto teóricas como prácticas en la enseñanza-aprendizaje de lenguas extranjeras.

Palabras claves: autoevaluación, autonomía del estudiante, constructivismo, investigación - acción, inglés como lengua extranjera (EFL)

\section{Introduction}

The theory on autonomy in language teaching-learning has been around for at least 40 years now. According to Benson, "the concept of autonomy first entered the field of language teaching through the Council of Europe's Modern Languages Project, established in 1971" (2013, p. 9). Readily, autonomy was defined as the capacity to take charge of one's own learning. As the concept of autonomy evolved, it became part of the main stream of research and practice in the field of language education. Alternatively, the increasing number of publications and on-going discussions on the subject pose themselves as an indicator of the growth of autonomy as a specialized field of inquiry (Benson, 2013). Thus, current authors such as Reinders (2010), Bhattacharya and Chauhan (2010), Tamjid and Birjandi (2011), Humphreys and Wyatt (2014), and many others, have addressed different issues of learner autonomy in Asia and Europe and have helped shape a better understanding of its fundamentals, present status, and future directions in research and practice. In Costa Rica, however, research on the area has been relatively scarce, carried out only by few authors such as Solano (2008), Barrantes and Olivares (2008), Chaves and Salazar (2013), and Sevilla and Méndez (2013).

This being the case, our motivation to do research on learner autonomy sparks off from two major sources. First, it emerges from an initial smallscale action research inquiry conducted by one of the researchers; this was a pilot plan that explored the connection between self-evaluation strategies and the development of learner autonomy in the context of English as a Foreign Language (henceforth, EFL) in an eleven-student phonetics class at a public university in Costa Rica. Two selfevaluation strategies were applied and evaluated for a period of eight weeks: the weekly plan and the student diary. The results of this initial inquiry suggested that learner autonomy can be enhanced through the application of self-evaluation strategies as the ones piloted, but it also called for further research on the application of the strategies studied. Second, a revision of the state of the art in the field of autonomy suggests that despite its significance in language education, little research has been done in the context of Costa Rica that examines the incidence of 
self-evaluation strategies and the promotion of learner autonomy.

So, the purpose of the research reported herewith was to study the connection between self-evaluation strategies (the student diary and the weekly plan) and learner autonomy in the context of EFL. Because the study set off to solve a pedagogical problem, this research was framed within the action research paradigm. For purposes of data analysis and discussion, the QUAL-quan model was selected since the study combined qualitative and quantitative data collection and analysis strategies. Roughly, findings suggest that self-evaluation strategies do assist the nurturing of learner autonomy, and that they are best cultivated when devised from a constructivist, self-discovery pedagogical framework.

This study provides insights for both theory and practice. At the theory level, it extends the body of empirical evidence for the promotion and development of learner autonomy; while at the same time it complements previous scholars' (e.g., Fernández, 2011) findings on effective strategies to attain this objective. At the pedagogical level, it suggests ways to make the language classroom a more democratic, self-directed, and constructivist landscape.

\section{Literature Review}

This research sought to determine the connections between self-appraisal strategies and the promotion of learner autonomy in the context of EFL. Because the educational setting where the study was run bases its pedagogical practices on the philosophy of Constructivism, the execution of our action research plan rested upon the central principles of this approach, which are discussed as follows.

\section{A Historical Overview of Constructivist Pedagogies}

As many language specialists and scholars have made it evident, constructivism as a language teachinglearning philosophy is hardly a new subject (Brown, 2000, p. 11). The emergence of constructivism came into existence as the antithesis of the rationalist, innatist and merely psychological views of learning that prevailed during the first half of the $20^{\text {th }}$ century. More specifically, the birth of Constructivism can be traced back to the emergence of the Humanistic Approach in the decade of the 70s, an approach that developed under the threshold of the humanist school of thought which considered the individual's emotions, personal dimensions, feelings and thoughts as central within all human progress (Wang, 2005, as cited in Solano, 2008, p. 182). Along with this, Solano explains, by the time Humanism came into fruition as a teaching approach, renowned scholars such as John Dewey, David Ausubel, Jean Piaget, and Lev Vigotsky had advocated for a type of teaching-learning that considered the role of "the social and the cognitive contexts" of the language instruction experience: Constructivism (pp. 182-183). As a result of these two approaches, the language classroom underwent "a shift in power" and roles; now "the teacher's role had become that of a counselor, guide or facilitator, letting students take center stage" (Solano, 2008, p. 183). 
But constructivism did not make its way through contemporary language education without its discrepancies. Two of the most recognized scholars in the subject, Jean Piaget and Lev Vigotsky, had polarized views regarding the scope and role of the social context in teaching and learning. For Piaget, an individual's cognitive capacity was a solitary act that depended largely on biological conditions: "biological timetables and stages of development were basic; social interaction was claimed only to trigger development at the right moment in time" (Brown, 2000, p. 11). For Vigotsky, however, the case was the complete opposite. For him, social interaction constituted the foundations of all cognitive development; he "rejected the notion of predetermined stages" (Brown, 2000, p. 11). All in all, it would be valid to say that Piaget held a more psychological notion of learning while Vigotsky advocated for a more socially conditioned nature of it.

In the context of contemporary language education, constructivist teaching rests more upon the foundations of the socially mediated than that of the merely psychologically conditioned, of which Piaget was a great advocate. For the purpose of our research, the action plan was formulated following the tenets of social constructivism, as it is popularly known today.

\section{The Role of Context}

Virtually anyone in the teaching enterprise would admit that context plays a central role in every language education setting; but context, as understood within what Tudor (2001) has described as "a new technology of language teaching” (p.5), can be more complex a construct than we generally realize. For one thing, context is not necessarily an external variable that affects the learner in a one-directional fashion. It is a rather more complex matrix of realities in the form of either micro or macro contexts, where the former is integrated by the immediate geographical and psychological elements of the learner's reality; whereas the latter refers to the broader political, historical, and ideological reality in which learning is framed (Brumfit, 1991, as cited in Tudor, 2001, p. 19). For another, the acknowledgment of this view of context presupposes that the instructional activity should be framed within context-bound pedagogies that take into account the learners' beliefs, expectations, and ethos of learning, as well as what society at large expects from them in the long run.

Because all learning happens within a given cultural and historical context, the pedagogical adaptations language instructors must perform in their everyday teaching are by far numerous and complex. On this, Brumfit has asserted that teaching is especially constrained by the context because the elements behind instruction are not only many, but usually conflicting (1991, as cited in Tudor, 2001). A potential solution to this, however, has been proposed by Tudor. In his book The Dynamics of the Language Classroom, this author states that given the many contextual constraints of language teaching, teachers need to take a stand in "exploiting local dynamics ( $p$. 157)"; which means studying elements such as the culture of learning, classroom and social behaviors, educational 
context, and other contextual variables in order to devise teaching methodologies that best cater to the type of population and goals we are dealing with. In the case of the present action research, the selection of the action plan was done following all of the principles discussed herein about the role of context in learning.

\section{The Role of the Learner}

Since the emergence of constructivist teaching back in the 1970's (Brown, 2000), a number of authors have conducted empirical studies and published theoretical reviews to illuminate the pedagogical practices that should gear the language education agendas. Examples of these authors include, amongst many others, Jonassen (1994), Matthews (2003), Nikita (2010), Kootze (2010), Sivasubramaniam (2011), and Richardson (2003), and they all have in one way or another contributed to answering the many questions that surround constructivist language teaching and learning. But for the purpose of the current study, we resolved to base our action plan in what Sivasubramaniam (2011) has considered the underpinnings of constructivist learning environments, which include: The view of knowledge as mutually constructed between learners and instructors, the use of authentic activities and tasks, the provision of "stimulus for reflecting on experience", and the acknowledgement of "collaborative construction of knowledge through interpersonal associations/negotiations" (p. 9).

In pedagogical practice, such principles are to be translated into opportunities for goal-setting and self-reflection, learner autonomy and initiative, and opportunities to become active members of the learning community and to be able to drive lessons and "negotiate strategies and alter content" (Watson, 2001, pp. 140). All of this, at the same time, can be harmonized with the principles of student-centered learning that has called the attention of many scholars in the past few decades (e.g., Gronich, 2004; Francess and Rose, 2009; Hickman, 2010; and Qasem, 2010).

\section{The Role of the Instructor}

Along with the idea that learners occupy an active role in the negotiation and construction of their knowledge, teachers are also attributed specific roles so that pedagogical practices account for true constructivist instruction. According to Sivasubramaniam, Brazilian pedagogue Paulo Freire has spoken of a need to shift from the traditional "banking-model of education" where the teachers would "deposit information into students as they would deposit money into a bank" (2011, pp. 9-10) to more problem-posing models of education where learning is treated as a dialogic process; as a more democratic practice; as a more literate undertaking.

On these same lines of argument, other current authors such as Virginia Richardson (2003) have proposed that constructivist pedagogies involve a series of intrinsic characteristics, such as:

1. attention to the individual and respect for students' background [...]

2. facilitation of group dialogue [...]

3. planned and often unplanned introduction of formal domain knowledge into the conversation through 
direct instruction, reference to text [...] or some other means.

4. provision of opportunities for students to determine, challenge, change or add to existing beliefs and understanding through engagement in tasks that are structured for this purpose; and

5. development of students' metawareness of their own understandings and learning processes. (p. 1626)

In the context of language instruction, Sivasubramaniam claims that constructivist teachers must "treat language as communication" (not as a merely formalist decoding or structure analysis), "optimize students' existing communicative competence" by developing systematic appraisal of the kind of teaching they do, and "foster cross-cultural sensitivity" through their language pedagogies (pp. 14-15). For the purpose of our paper we have summarized the role of the instructor in language teaching as: co-constructors of knowledge, negotiators of learning opportunities, facilitators of communication opportunities and reflection, and guides in the discovery of cultural, linguistic, pragmatic and semantic elements of language instruction and learning.

\section{On Learner Autonomy}

As many experts in the area have agreed, learner autonomy is by far an intricate construct. According to Tudor (2001), the works by authors such as Benson (1997), Pennycook (1997), Usuki (1999), among others, are but an example that the body of literature on learner autonomy is both vast and developing, which makes it difficult to claim for a universal definition of the construct. But, as the author goes on to explain, Usuki (1999) has outlined two perspectives of learner autonomy: The psychological and the political perspectives, which are particularly pertinent within the scope of our research. The psychological perspective on autonomy deals primarily with "autonomy for language learning" (Tudor, 2001, p. 119). It is concerned with the extent to which the learner is able to undertake a participatory role in the language learning process, and it views the learning agenda as negotiated between instructors and students. Closely connected with the concept of learner involvement, this perspective advocates for a type of education where the learner engages in decision making, goal-setting, and the negotiation of the content to be processed throughout the program. The political perspective, alternatively, has to do with autonomy that transcends the classroom boundaries of learning. It is mostly concerned with the degree to which learning has social and/or cultural repercussions. From Tudor's (2001) standpoint, the political perspective conceives the individual as evolving from "language learner to language user" (p. 118), which bears implicitly the idea that language instruction should be oriented towards the creation of individuals capable not only of meeting the economic demands of our society but also evaluating, critiquing, and proposing solutions to the many complexities that surround human development.

Naturally, the study of the political perspective on autonomy would require longitudinal studies that examine the impact of language instruction in the social, cultural, and political systems 
where the individuals function. Because of the complexity that this represents, it is the psychological perspective on autonomy with which this paper is concerned. Given that the English program had already-fixed goals and objectives and therefore allowed for little modifications in their organization, the action plan sought to give the students a chance to nurture their self-learning capabilities both in and out of the classroom. In this manner, not only did they get a chance to cultivate self-directed learning and linguistic empowerment but also stuck to the curricular goals established in the program.

With this in mind, and in order to provide some perspective on the status quo of self-evaluation and learner autonomy, a brief discussion of sample publications of the past four years is provided in the lines that follow.

\section{Recent Studies on Self-Evaluation and Learner Autonomy}

In his article, Towards a Classroom Pedagogy for Learner Autonomy: A Framework of Independent Language Learning Skills, Reinders (2010) explored some of the teaching aspects related to the development of learner autonomy and proposed a framework of skills that could be used by teachers as a guide to increasing learner responsibility. His paper was concerned mainly with the practical operationalization of learner autonomy and its implementation in the language classroom as he argued for a learner-autonomy based pedagogy. Therefore, the framework proposed is operationalized starting from the learner and his or her actions which in time can be encouraged, modeled, and monitored by the teacher. He concluded that developing autonomy is a lengthy process and that the implementation of the framework proposed does not guarantee that students will develop autonomy but, he argues, will shift focus from the teacher to the learner.

In another study, Bhattacharya and Chauhan (2010) investigated the effects of blogging on the development of autonomy in a study conducted in India. They had 35 students in the second year of their Master's in English Language Teaching (ELT) courses create blog reports at the end of a onemonth project in order to study the relation between learner autonomy and blog-assisted language learning. Their findings revealed that blogging impacted positively the development of learner autonomy constructs such as independent decision making skills, independence, and intrinsic motivation, among others. They concluded that blogging gives voice to students and in so doing it could provide a meaningful purpose for triggering off other attendant language-learning constructs like motivation and cognitive skills in an autonomous setting.

Along the same lines, in his article, Misconceptions on Learner Autonomy: A Methodological and Conceptual Renewal, Asik (2010) asserted that learner autonomy is the result of methodological innovations in second and foreign language teaching, especially in communicative language teaching and learner-centered approaches. He claims that while discussing and implementing a point of view in language teaching which places learner autonomy as a top priority, many misconceptions have aroused. Therefore, his 
study set forth to debunk some common misunderstandings about learner autonomy by addressing related terms and issues. His study proposes a process that includes the necessary phases to enhance autonomy in language teaching through disregarding the existing misconceptions. He arrives at three central conclusions: First, that learner autonomy does not mean learning in isolation. Learners develop a sense of interdependence with teachers and peers towards shared goals; second, terms such as individualized learning, self-directed and self-instructed learning are in a way related to autonomy but that this does not mean that they are the same; and third, teachers should be attentive with the concept of autonomy and the ways in which it can be used and encouraged in foreign language teaching as its operationalization has not yet reached solid consensus.

One year after the publication of Asik's paper, Tamjid and Birjandi (2010) conducted a quasi-experimental, nonrandomized control group, pretestposttest design study at Islamic Azad University of Tabriz that explored how self and peer-assessment as compared to teacher assessment could promote Iranian EFL learners' autonomy. They found out that the incorporation of self and peer-assessment enhance the students' autonomy.

Later on, in 2013, Oguz investigated teachers' views on supporting learner autonomy in the province of Kütahya, Turkey. The study included 492 teachers working in the primary and secondary public school system. The research design was based on a survey model. The author found that teachers ranked learner autonomy supporting behaviors as always being necessary, while in classroom practice they demonstrated these behaviors only most of the time. A major conclusion in this study is that teachers' view on the necessity of autonomy support is at a higher level than their view on its demonstration and that because of this teacher training with regards to the demonstration of autonomy supportive behaviors is necessary.

Even more recently, Humphreys and Wyatt (2014) investigated learner perceptions and practices regarding autonomy and collaboratively proposed ways to improve its promotion in an EAP program at an international university in Ho Chi Minh City with Vietnamese learners. Through their collaborative action research, they found that the weak top-down approach to supporting autonomy employed at the university was inadequate. Therefore they formulated an intervention which they applied for five weeks. Thus they were able to conclude that socially mediated support for autonomy can help learners take greater control over their own learning.

The review of recent publications on the topic of student autonomy development and the different strategies used to prompt its development (Reinders, 2010; Bhattacharya and Chauhan, 2010; Asik, 2010; Tamjid and Birjandi, 2011; Oguz, 2013; Humphreys and Wyatt, 2014) yields a number of conclusions that merit attention. First, learner autonomy is a desirable characteristic of second language learners. Second, learner autonomy development is a complex issue that needs more attention on the part of researchers and teachers alike. Third, because of the several misconceptions and misunderstandings, the term needs to be 
clarified and redefined. Fourth, teacher awareness and training regarding learner autonomy is necessary in language education institutions. Fifth, different frameworks, methodologies, and strategies have proven to enhance learner autonomy development. In the particular context of Costa Rica's language education, however, research on learner autonomy is rather scarce in comparison to the volume of research conducted on areas such as methodology and program development. Because to date no research has been conducted that explores explicitly the link between self-evaluation strategies and the promotion of learner autonomy, our research sought to tackle this issue through the implementation of an action research project, as described in the section that follows.

\section{Methodology}

This section presents a description of the methodological procedures used in the completion of this research.

\section{Research Method and Design}

Because this study set off to solve a pedagogical problem which was particular to a specific educational setting, this research is best framed within the action research method; also referred to as classroom research or teacher research (Efron and Ravid, 2013, p. 2). As Efron and Ravid acknowledge, action research is particularly useful today because it allows teachers to devise their own solutions to problems that arise in their very educational contexts, which cannot be formulated through the traditional top-down educational recipes dictated from outsider experts of the field. In the action research process, the researcher embarks on a three-stage process which, according to Richards and Lockhart (1994), gives way to the on-going development of educational change. In the first stage, the researcher-practitioner conducts an initial reflection on a given phenomenon by identifying an educational need or problem. Once this reflection has been completed, the researcher formulates an action plan that seeks to bring about changes to such need or problem. The last stage comprises the systematic observation of the interaction between research participants and the action plan implemented. Upon completion of these three stages, the reflection process may start over so as to further assess the feasibility of the action plan and to devise future courses of action along the lines of the problem identified. For the purposes of the present research, these stages are described in detail in the procedures section.

Because the study combined qualitative and quantitative data collection strategies and instruments, for purposes of data analysis and discussion, we selected the triangulation mixed methods design, also known as the "QUAN-QUAL model". In this type of research design, qualitative and quantitative data are collected and analyzed concurrently throughout the same study, and the weaknesses of the quantitative approach are counterbalanced with the strengths of the qualitative one and vice versa (Gay, Mills, and Airasian, 2009, p. 463). The conjunction of these two research designs allowed for a more thorough analysis and discussion of the results, as well as to blend the "research-then-theory" 
and the "theory-then-research" approaches that for decades divided the educational research agenda in the past (Ellis, 1990, pp. 4-5).

\section{Participants and Context of the Study}

The study was conducted in the IO-5309 English Phonology course, a second-year class (IV cycle) of the English Teaching Bachelor's program at a public University in Costa Rica. Participants were a heterogeneous group of students aged 18 to 25 with diverse interests, backgrounds, learning styles, intelligence type, and genders. All the participants were full time students, and at the time of the study all of them had enrolled in all the seven classes in the IV cycle of the program. This was a four-hour a week, one-semester long class taught in the afternoons.

\section{The Data Collection Instruments}

For the sake of clarity, the first two instruments were used as a means to implement the strategy and the third one was used to assess the usefulness of the strategy from the participants' perspective.

The first instrument was the weekly plan (see appendix 1), which came about as a recommendation from the professional literature on the field (i.e., Calatayud, 2008). In this instrument, students were asked to keep track of their out-of-class learning activities related to the course, and it included two sections. The first section was designed in a five-column format and asked participants to record the content to be learned each week, the homework assigned for each week, the schedule to do that homework, a self-designed activity aimed at learning the content for each week, and the schedule to do the self-designed activity. In the second section, participants had to write a reflection assessing their plan for each given week. Such reflection was prompted by three questions: How did the different activities help you learn the contents for this week? What part of the content, if any, couldn't you learn? How difficult or easy was it for you to meet the schedule you set to accomplish the activities?

The second instrument was the student diary (see appendix 2), adopted from Fernández (2011). Here, participants were asked to keep a threeentry diary which they submitted for feedback on a weekly basis. Each of the entries in the diary was prompted by a question; and it also featured a section for instructor feedback.

The third instrument was a strategy-assessment checklist designed by the researchers (see appendix 3) for participants to assess the experience of keeping the weekly plan and the student diary. The checklist featured eight statements organized in three sections: Statements referring to the weekly plan, statements referring to the student diary, and statements referring to the experience in general, which were marked: $1=$ nothing, $2=$ a little, $3=$ quite a bit, and $4=$ very much, according to how the participant felt about the content in each statement. This instrument was administered at the end of the semester and yielded data that helped voice out the students' opinions regarding the self-appraisal strategy as a whole. 


\section{Research Procedures}

Three stages comprised the maturation of the action plan. In the first stage, one of the researchers observed that the students had trouble taking charge of their own responsibilities, especially with the completion of homework and time organization. This reflection was conducted during year 2013 and hence a small-scale action plan was piloted (as described in the introduction of this paper). In 2014, we devised a more solid action plan that took into account the weaknesses and strengths of the small-scale plan and ran it with the participants described above. In the last stage we collected data from the participants using the student diary, the weekly plan, and the strategy assessment checklist.

For the purpose of action plan implementation, the weekly plan and the student diary were used on a weekly basis during the application of the strategy. Participants filled in the instruments and handed them in to the instructor weekly for a 15 -week period (a term). The instructor checked the weekly plans and the student diaries, included individualized feedback, and returned the instruments to the participants every week. This constituted the strategy. As we have stated, the self-assessment checklist was used at the end of the semester for participants to assess the strategy.

\section{Validation Techniques}

For purposes of methodological validity, we followed two basic procedures. We first accounted for content validity by making sure that the content of the data collection instruments matched entirely the research objectives and the research design selected. In addition to this, the content of the instruments was drawn from those elements that the professional literature on the field (e.g., Fernández, 2011; and Calatayud, 2008) recognizes as suitable for student self-appraisal and autonomy development. Once we satisfied content validity, we pilot-tested the instruments. Because this study departed from a previous small-scale study where the same instruments were administered, the present study took advantage of the experience and fine-tuned such instruments based on weaknesses outlined during the conduction of the first study.

\section{Data Analysis Techniques}

This section displays the data analyzed for both the qualitative and quantitative data collected via the three research instruments. Our analysis is both, descriptive and explanatory, and it presents two major perspectives. On the one hand, qualitative data are analyzed through the researchers' lens as it draws from sample journals and weekly plans, and it is framed within two major categories (i.e., (1) positive outcomes and (2) major difficulties faced by the students) that emerged from these two instruments. On the other hand, the students' perspectives on the contribution of the strategy to their autonomy development are examined based on quantitative data yielded by the strategy-assessment checklist. Hereafter, we go on to discuss the results in light of our research question and the professional 
literature discussed in the literature review section of this paper. This discussion is also based upon the theoretical constructs of the role of the student, the role of the teacher, the role of the context, and constructivism in language teaching.

\section{Analysis of the Results}

As stated earlier in this paper, our research set out to determine possible relations between self-evaluation strategies and the promotion of learner autonomy in an EFL classroom at a public university in Costa Rica. Thus, this section presents an analysis of the quantitative and qualitative data drawn from the study's participants. In the subsection The Researchers' Perspective, we analyze the results of the action research plan implementation from the professional and scientific standpoint of the researchers. In the subsection The Students' Voices, the students' perceptions of the action research plan are voiced out by analyzing their appraisal of the autonomy development strategy.

For purposes of confidentiality and reader's traceability, we have created a table of codes for direct citation of qualitative information, which can be seen in table 1 below.

Table 1: Qualitative Data Citation Codes

\begin{tabular}{lll}
\hline \multicolumn{1}{c}{ Instrument Type } & \multicolumn{1}{c}{ Data Source } & \multicolumn{1}{c}{ Citing Code } \\
\hline Weekly Plan & Phonetics Class Students & WP 01-018 \\
Student Diary & Phonetics Class Students & SD 01-018 \\
Strategy-assessment Checklist & Phonetics Class Students & SAC 01-018 \\
Student Diary & Course Instructor & SD-CI 01-018 \\
\hline
\end{tabular}

Source: Researchers' own design

In the analysis that follows, direct text gathered from the weekly plan will be cited as WP 001 up to 018, which was the total number of students who participated in the research. This means that direct text coming from student 11, for instance, will be cited as WP 011. Correspondingly, direct citations from the same student but from the student diary will be coded as SD 011; and from the strategy-assessment checklist: SAC 011. Lastly, since the student diary included a section for instructor feedback, any comments cited from this part will be coded as SD-CI, where CI means instructor comments.

\section{The Researchers' Perspective}

\section{Positive Outcomes}

By and large, data in the student diaries show a reasonable clear link between self-evaluation strategies and learning autonomy development. As we gathered data and drew relations among them, it became evident that 
such positive outcomes could be better described and interpreted if grouped into two main subcategories.

The first subcategory deals with students' sense of interconnection among the already-studied contents. On this, we found that the action plan nurtured a feeling of continuity between the course content studied in previous lessons. For instance, participant 016 reports that the weekly plan helped him revise the topics studied: "it was very useful to me [the weekly plan] in order to revise the topics we got before" (WP 016, Sic.). Participant 07, likewise, stresses that the weekly plan assisted him in processing the contents as he was able to revisit them for better understanding. In this student's own words, "the activities [planned in the weekly plan] helped me to learn the contents because I studied them again for understanding them better." (WP 007, Sic.).

The second subcategory has to do with students' sense of achievement, which was reported at, at least, three different levels: linguistic, affective, and organizational. At the linguistic level, evidence mainly from the student diaries suggests that the participants held a positive perception of their own language development upon partaking in the project. Participant 5, for instance, reports: "the activities have helped me to know more about pronunciation and to know more about where the places of articulation are" (WP 005); while a second participant, along with the above, states: "I learned that when I speak I don't have to articulate some words, which is called neutralization" (SD 007). From these two quotes, we can realize that the students were able to consciously analyze their linguistic evolution in the course, particularly on how speech articulation and accent neutralization occur in the speech apparatus. But in addition to this, data suggest that they also became aware of the importance of vowel articulation in the paralinguistic dimension of speech, as made evident by participant 3: "[this lesson helped me to learn] vowels with communicative meaning-I can express different emotions in English by pronouncing vowels in a certain way" (SD 003). As we can appreciate here, this participant is aware of the role processes such as vowel prolongation or reduction exerts in conveying a given emotion or communicative intention, an accomplishment that merits attention because paralinguistic features in foreign language learning usually turn out challenging to learners, and even more so at beginning stages of their interlanguage. Further down the same diary entry, this participant reports sense of achievement in terms of prosody, when she points out that she believes "learning phonetic processes-suprasegmentals - improve the way you sound when speaking English" (Sic).

As for the case of the affective level, data from the student diaries indicate that participants believe the project positively impacted their affective domains. For instance, on being asked how they had felt about the lessons, participant 15 has pointed out: "I felt fantastic, because we practiced a lot about sounds and details, something that I enjoyed [...] I feel I improved [my participation] according to my participation last week" (SD 015, Sic.). Along with this, participant 2 has stated: "I felt great because I understood the content we covered without 
any problems. I think I am improving my pronunciation skills [...] and learned new vocabulary" (SD 002). As we may notice from these quotes, both these students perceive classes to have yielded positive outcomes on their affective dimensions; but if we analyze the data in detail, we realize that they do not perceive the project as having impacted just their affective domains. Instead, they perceive the affective and the cognitive sides of learning to have overlapped, as their positive feelings about the lessons are the result of having been able to achieve the cognitive mastery of the class (i.e., pronunciation skills and vocabulary learning). Hence, we could call this a teaching breakthrough, since, as it has been shown in recent research, the affective domain has remained neglected because of the generally held belief that the cognition is more important than the affection (Sevilla, 2014).

That said, the third level of sense of achievement reported by the participants is time organization, chiefly in the weekly plans. By and large, students had trouble meeting their schedules in the first seven or eight weeks of the semester, mainly, as they make it evident, because they had too many assignments and they were not used to meeting schedules. Nonetheless, by week nine, most of the participants started to state that they were being able to meet their schedules successfully. Participant four, for instance, by week ten, reported: "this time was easy for me to meet the schedule I set because I organized my time very well" (WP 004, Sic.). Three weeks later, this same participant goes on to state: "it wasn't difficult for me to meet the schedule I set". Another participant, along the same lines, affirms: "[on week 12,] I got to meet the schedule I set so I accomplished my self-designed activities" (WP 003). As one may see from these data, there is an evolution in the organizational side of the learners that, apparently, did not exist before the students were immersed in the project. What stands out from this evidence is that there is a rupture in the participants' ethos of learning; that is to say, there seems to be a change in the culture of learning that is shifting from disorganized to organized; from not being able to take charge of their own responsibilities to a more mature way of coping with academic assignments, a point worth discussing if we keep in mind that (1) these students were only in their second year of their English teaching major and that (2) they are preparing to become teachers, a profession that, as anyone knows, demands a lot of planning and organization.

\section{Major Limitations Faced by the Students}

To continue with our discussion on the link between self-evaluation strategies and learning autonomy development established through the examination of date obtained via the weekly plans and the student diaries, at this point it becomes necessary to discuss some of the major challenges faced by the students. Such difficulties can be grouped into two categories.

The first category refers to time management where three difficulties were evident. Fist, students found it difficult to follow the schedules set for homework and other out-of-class 
activities. To exemplify, participant 005 reported: "Finally this week I have been practicing but is very difficult organize the time" (WP 005, Sic.). In turn, participant 016 asseverated: "It was so hard to follow my schedule, because I didn't be aware about how much time I spent in other activities, however this week I got to invest more time in my schedule" (WP 016, Sic.). Second, students experienced trouble organizing time. As a way to illustrate, participant 005 reported: "[...] This week I have been practicing but is very difficult organize the time" (WP 005, Sic.). Third, the workload, especially in the form of homework, was perceived as an obstacle that kept students from meeting their schedules. Participant 004, for example, declared: "To meet the schedule was a little difficult because I had a lot of homework [...]" (SD 004, Sic.); while student 015 complained: "[...] like in every course the variety of homework is the only limitation" (WP 015, Sic.). As evidenced in these data, there is a culture of learning that surfaced in the participants' assertions; a difficulty setting priorities (they had trouble setting the schedule), which has to do, as stated elsewhere in this section, with the students' ethos of learning. Also, a feature that stood out here was the students' perception that the system saturates them with too much homework, which affected their meeting of the schedule.

The second category has to do with the mastery of content. Through the student diaries and weekly plans, participants were able to reflect upon the bits of content that were difficult for them. Such was the case with participant 017, who experienced trouble mastering phonetic symbols: "I couldn't identify the well the symbols that I have to use for each sound in every word that I had to transcribe" (WP 017, Sic.). This was also the case with participant 002, who had difficulties with tongue twisters: "The content in general wasn't really difficult but something that give me problems is, in some cases, the tongue twisters" (WP 002, Sic.); or participant 003, who reported to find omission difficult to learn: "I didn't feel good because I find the content regarding omission, difficult to lean there are many cases and rules." (SD 003, Sic.). Along with this, in the weekly plan this student points out: "I need to practice more regarding cases where omition occurs" (WP 003, Sic.).

On first hearing, the students' report of difficulties in learning certain course contents might be perceived as a limitation. However, on a closer look at the issue, what this suggests is that students were able to become aware of the areas that needed improvement. This awareness, at the end, is actually the goal of every teaching that seeks autonomy development in learners.

\section{The Students' Voices}

As stated previously, the third instrument of three used in this investigation was utilized to assess the usefulness of the strategy from the participants' perspective. Their voices are echoed in the paragraphs to come through the analysis of their views on the usefulness of the weekly plan, the student diary and the strategy in the development of learner autonomy.

The Weekly Plan aimed at assisting students in organizing time, learning of contents, taking charge of their own 
responsibilities and reflecting upon their learning. The data in table one shows that clearly the Weekly Plan served its purpose. All in all, most of the students reported that this instrument helped them to effectively organize time, learn the contents of the week, and think over their own learning. Interestingly, a small percentage of the students reported that the weekly plan did not help them to take charge of their own responsibilities. All of this strongly suggests that the use of a weekly plan as a strategy to promote the development of learner autonomy is effective from the view point of the student. Table 1 below details these numerical data.

Table 1: Student Perception of the Impact of the Weekly Plan on their Learner Autonomy Development

\begin{tabular}{|c|c|c|c|c|}
\hline Criteria & Nothing & A little & Quite a bit & Very much \\
\hline \multicolumn{5}{|l|}{ THE WEEKLY PLAN helped me to: } \\
\hline effectively organize my time. & & $16,66 \%$ & $55,55 \%$ & $27,77 \%$ \\
\hline $\begin{array}{l}\text { better learn the contents proposed for } \\
\text { the week. }\end{array}$ & & $11,11 \%$ & $50 \%$ & $38,88 \%$ \\
\hline $\begin{array}{l}\text { take charge of my own } \\
\text { responsibilities. }\end{array}$ & $5,55 \%$ & $11,11 \%$ & $38,88 \%$ & $44,44 \%$ \\
\hline $\begin{array}{l}\text { think over my learning actions of the } \\
\text { week. }\end{array}$ & & $16,66 \%$ & $16,66 \%$ & $66,66 \%$ \\
\hline
\end{tabular}

Source: the authors' own design

The student diary, in turn, purported to help the participants become aware of their role as learners and see how the class aided them in their learning process. Data show that the goal was attained since all students reported that the diary allowed them to recognize their role as learners, as it also assisted them in visualizing how the class contributed to their overall language instruction. The implication is clear-cut: the student diary does work as a means to prompt learner autonomy, as shown in table 2 below.

Table 2: Student Perception of the Impact of the Student Diary on their Learner Autonomy Development

\begin{tabular}{|c|c|c|c|c|}
\hline Criteria & Nothing & A little & Quite a bit & Very much \\
\hline THE STUDENT DIARY helped me to: & & & & \\
\hline become aware of my role as a learner in class & & $5,55 \%$ & $44,44 \%$ & $50 \%$ \\
\hline $\begin{array}{l}\text { clearly see how the class contributed to my } \\
\text { learning }\end{array}$ & & $5,55 \%$ & $22,22 \%$ & $72 \%$ \\
\hline
\end{tabular}


The general strategy, that is, the use of the student diary and the weekly plan in the way and for the time period described elsewhere in this article, had a two-fold purpose. On the one hand, it intended to motivate students to do more for their learning than what was required in the class; on the other, it purported to make them more independent in the course. According to the data examined, the strategy was successful because students noted that it did motivate them to walk the extra mile in their intent to learn the contents; they also made it evident that they became more independent. It then should be asserted that the strategy was fruitful in prompting learner autonomy development. Table three below details these numbers.

\section{Table 3: Student Perception of the Impact of the Strategy on their Learner Autonomy Development}

\begin{tabular}{|c|c|c|c|c|}
\hline Criteria & Nothing & A little & Quite a bit & Very much \\
\hline \multicolumn{5}{|l|}{ THE STRATEGY: } \\
\hline $\begin{array}{l}\text { motivated me to do more than required to } \\
\text { learn the class contents }\end{array}$ & & $5,55 \%$ & $33,33 \%$ & $61,11 \%$ \\
\hline $\begin{array}{l}\text { made me more independent as a learner } \\
\text { in this course }\end{array}$ & & $11,11 \%$ & $38,88 \%$ & $50 \%$ \\
\hline
\end{tabular}

\section{Source: the authors' own design}

\section{Discussion of Findings}

Having described and analyzed the data in the preceding subsection, we now shift our focus to discussing and theorizing the major findings based on our research objective and the professional literature reviewed.

The first major finding comes along from the lens of both researchers and students. On this, we found out that the action plan yielded positive results in terms of students' sense of interconnectedness of the contents studied and their sense of achievement in the course. Among some plausible explanations for these findings are the conjunction of elements such as the role of context, the role of the instructor, and the role of the learner, especially if we bear in mind that the class was heterogeneous in terms of ages, interests, sociocultural backgrounds, and type of intelligences and learning strategies. Earlier in this paper, we went through Tudor's (2001) notion of context as not being one-directional but rather dynamic and multilayered, as well as framed within a particular political, historical, and ideological setting. In the case of our project, since the plan emerged as an initiative to attend to a need as detected through systematic teacher observation (before the actual formulation of the project), the positive outcomes can be linked to the design of a pedagogical intervention that focused on the micro context where the class was being taught. This hints out that, had the action plan been designed by 
an outsider expert, as it has been traditionally the case in some language institutions, the findings may have varied significantly. The findings also support Reinder's (2010) idea that while learner autonomy cannot flourish in a short period of time, its development can be boosted through systematic teacher's monitoring; and also Asik's (2010) conclusions that autonomy is the product of continuous pedagogical innovation in the language teaching scenario.

Another element that may have influenced the project's positive results is the synchronization of the role of the instructor with the students' responses to it (the learner's role). In constructivist language teaching, effective instruction is that which gives students the chance to participate actively in goal-setting, content coverage, and reflection, among others. Since the project allowed the students to set their own goals and chose their own self-assessment strategies, we hypothesize that the positive appreciations they had about their own autonomy development are in part because of the active, constructivist role they took on. The instructor's role as a guide and facilitator of learning opportunities, on the other hand, was a medullar element throughout the action plan, as it is shown by data from one of the diaries, where a student complained that he had been struggling too much to process the subject matter, and the instructor replies: "sorry to hear that. If that's the case always talk to me and let me know so we can figure something out" (SD-IC 017). On analyzing the different data sources, we cannot see these two variables as separate elements, but as overlapping components that amalgamated to aid autonomy development.
At this point, it is important to go back to the operationalization of autonomy as reviewed by Tudor (2001). As the author explains, autonomy can be developed at either the psychological or the political levels; the first one being (in its simplest definition) autonomy for learning and the latter meaning autonomy that has social and/or cultural repercussions in the long run. If we take a look back at our data analysis, we realize that what the students report is mostly related to autonomy in its psychological scope, a finding that should not be surprising if we remember that autonomy at the political level can be developed and verified only throughout long periods of time.

That having been said, the second major finding comes from the perspective of the students, who assessed the autonomy development strategy as generally positive, both in their quantitative and qualitative evaluations of it. On this, they pointed out as their major challenges time management and mastery of linguistic content. In thecaseoftime management, this finding suggests that either (1) the students were just sticking to a culture of learning (a modus operandi) that is customary in their language learning setting (procrastination and the like), or (2) homework and their academic load in general were placing too much pressure on them. In the case of content mastery, we made the point in the preceding lines that if this may appear as a limitation, it is in reality an achievement because the participants became aware of their own weaknesses, which is a crucial step in the shaping of learner autonomy. But beyond these seeming obstacles, what stands out is that the 
participants were able to reflect on their own progress, a desired characteristic in constructivist teaching-learning (see Sivasubramaniam, 2011). Along with this, this finding echoes Reindeer's (2010) conclusion that autonomy development is not only a complex but also a lengthy process, as well as Tamjid and Birjandi's (2011) finding that selfassessment helps enhance autonomy.

In general, the findings suggest the strategy has been perceived as highly successful on the part of both participants and researchers. But most importantly, they indicate that by being able to pinpoint their own limitations in the completion of the action plan, the students have started to walk their first steps into what Tudor (2001) has called the political dimension of autonomy.

\section{Conclusions and Implications}

As stated elsewhere in this paper, this study set out to examine the link between self-evaluation strategies and learner autonomy in a public university in Costa Rica. Upon its completion, we have arrived at three major conclusions.

First and foremost, there is a connection between self-evaluation strategies such as the ones used in this action plan and the nurturing or student autonomy, as evidenced in the positive appraisal of researchers and participants alike. The study complements previous assertions by Fernández (2011) that, out of the whole inventory of autonomy development strategies, weekly plans and student diaries help build up the essentials of learner autonomy.

In the second place, the study allows to conclude that autonomy is something that can and must be fostered. While it is not something one can teach as a discipline or as content per se, it is a life-skill that can be nurtured through strategies such as the one implemented herein. Self-discovery and students' opportunity to set their own goals play a crucial role on this, especially in a constructivist context where the learning experience is to be shaped not so much by outsider experts, but by what the students consider to be their major learning needs and wants.

A third conclusion is that promoting autonomy is a paramount need. As researchers, we observed that students had difficulty organizing their time and meeting the tasks proposed in the weekly plans, which implies that issues such as time management and procrastination may be left unattended if teachers do not overtly address autonomy in class. The occasion may well serve to claim that, as suggested by Richardson (2003), instructors are responsible for a great share of the work, chiefly the implementation of constructivist teaching principles such as guiding the students into constructing knowledge, set up "opportunities for students to determine, challenge, change or add existing beliefs and understanding through engagement in tasks that are structured for this purpose" (p. 1626), and their awareness of their own limitations in the learning process.

Lastly, although the study focused on the connections between self-evaluation strategies and learner autonomy, the findings may well have a bearing on how to approximate more to the implementation of constructivist pedagogies, a central element not only in the context of the study, but also in the educational agendas of many language institutions in Costa Rica and worldwide. 


\section{Limitations and Future Research}

While findings were generally positive, we have identified three major limitations that need to be acknowledged and tackled in further research. Since the study was limited to a small sample population, it can only account for what was done within the constraints of the action plan; naturally, then, we cannot imply that this will solve the problem of autonomy in contexts elsewhere. An additional uncontrolled limitation is the fact that we cannot assure that students will keep on approximating to the political dimension on autonomy unless enforced and verified through further, longitudinal studies. A last limitation is comprised by the scope and depth of the study, which, in turn, limits the transferability of findings to larger populations. Henceforth, only more research will finally prove whether our teaching paradigm will render the positive outcomes it rendered in our study.

On this, we suggest that future research studies adopt bottom-up rather than top-down (i.e., outsider expert) methodologies. We support this type of research because it allows for the local solving of educational needs, as it allows the teacher-researcher to engage in a process of continuous inquiry that does not end upon conclusion of the study, but continues to shape and reshape the teaching enterprise until more solid, context-bound pedagogical models are finally devised.

All things considered, we would like to conclude by reiterating the need to undertake similar research projects in EFL contexts, as well as to work collaboratively with fellow teachers, researchers, and institutional authorities alike. But, most importantly, we need to assist our students in developing their own autonomy habits and strategies for life, which is best summarized in the old proverb: "if you give a man fish, you will feed him for a day; but if you show him how to catch fish, you will feed him for a lifetime."

\section{Bibliography}

Asik, A. (2010). Misconceptions on learner autonomy: a methodological and conceptual renewal. Ekev Academic Review, 14 (43), 141-152.

Barrantes, L., and Olivares, C. (2008). A Closer Look into Learner Autonomy in the EFL Classroom. Revista de Lenguas Modernas, 19, 325-343.

Bhattacharya, A., and Chauhan, K. (2010). Augmenting learner autonomy through blogging. ELT Journal: English Language Teachers Journal, 64 (4), 376-384. DOI: 10.1093/elt/ccq002

Benson, P. (2013). Teaching and Researching Autonomy. New York, NY: Pearson Education.

Brown, D. (2000). Principles of language learning and teaching. White Plains, New York: Longman.

Calatayud, S. A. (2008). La autoevaluación como estrategia de aprendizaje para atender a la diversidad. Recuperado de: http://www.educaweb. com/noticia/2008/01/28/autoevaluacion-como-estrategia-aprendizaje-atender-diversidad-2752/

Chaves, O. and Salazar, E. (2013). Plans of Improvement: A Resource to Enhance Performance and Autonomy in EFL Courses. Revista de Lenguas Modernas, 18, 285-298. 
Ellis, R. (1990). Instructed second language acquisition: Learning in the classroom. Oxford, OX, UK: B. Blackwell.

Efron, S. and Ravid, R. (2013). Action research in education: A practical guide. New York: Guilford Publications.

Fernández, S. (2011). La Autoevaluación como Estrategia de Aprendizaje. Marcoele Revista de Didáctica Español como Lengua Extranjera, 13, 133-144.

Francess, J, and Rose, S. (2009). Agnostics, Skeptics, and Believers: Writing Teachers' on Student-Centered Teaching. [Doctoral Dissertation]. Purdue University.

Gay, L. R., Mills, G. E., and Airasian, P. W. (2009). Educational Research: Competencies for Analysis and Applications. Upper Saddle River, N.J: Merrill/Pearson.

Gronich, L. (2004). Towards an Understanding of What it Means to be Student Centered: A New Teacher's Journey. Journal of Management Education, 28 (4), 447-462.

Hickman, T. (2010). Culture Change: Defining and Measuring Student-centered Teaching. [Doctoral Dissertation]. Toledo, Ohio: University of Toledo.

Humphreys, G., and Wyatt, M. (2014). Helping Vietnamese university learners to become more autonomous. ELT Journal: English Language Teachers Journal, 68 (1), 52-63.

Jonassen, D. H. (1994). Thinking technology: Toward a constructivist design model. Educational Technology, 34 (4), 34-37.

Kootze, B. (2010). Seven posers in the constructivist classroom. London ReviewofEducation, 8(2), 187-187.DOI: 10.1080/14748460.2010.487340

Matthews, W. J. (2003). Constructivism in the Classroom: Epistemology,
History, and Empirical Evidence. Teacher Education Quarterly, 30 (3), 51-64.

Nikita, L. (2010). Addressing pedagogical dilemmas in a constructivist language learning experience. Journal of the Scholarship of Teaching and Learning, 10 (2), 90-106.

Oguz, A. (2013). Teacher's views about supporting learner autonomy. (English). International Journal Of Human Sciences, 10 (1), 1273-1297.

Qasem, R. F. (2010). The Relationship between PostSecondary Foreign Language Teachers' Beliefs in Student-Centered and their Educational Technology Practices. [Doctoral Dissertation]. North Central University. Reinders, H. (2010). Towards a Classroom Pedagogy for Learner Autonomy: A Framework of Independent Language Learning Skills. Australian Journal of Teacher Education, 35 (5). DOI: org/10.14221/ajte.2010v35n5.4

Richardson, V. (2003). Constructivist Pedagogy. Teachers College Record, 105 (9), 1623-1640

Sevilla, H. (2014). The Road not Taken: The Intersection of Contextual and Affective Factors in EFL Poetry Writing (unpublished Masters Degree thesis). Universidad Nacional, Heredia, Costa Rica.

Sevilla, H., and Méndez, G. (2013). Proceedings of the 11th Hawaii International Conference on Education: Reading in the EFL Classroom: A Model to Promoting Student Centeredness, Selfconfidence, and Critical Thinking in Oral Communication Courses. 06-11 Jan. 2013, Honolulu, Hawaii. Sivasubramaniam, S, (2011). Constructivism in EIL: Issues and Insights for Teaching and Research. 
Journal of English as an International Language, 6 (1), 1-20.

Solano, A. T. (2008). The Role of EFL

Teachers in the ESL Setting. Revista Letras, 2 (44), 179-191.

Tamjid, N. and Birjandi, P. (2011). Fostering learner autonomy through self- and peer-assessment. International Journal of Academic Research, 3 (5), 245-251.
Tudor, I. (2001). The Dynamics of the Language Classroom. Cambridge: Cambridge University Press.

Watson, J. (2001). Social Constructivism in the Classroom. Support for Learning, 16 (3), 140-147.

\section{Appendices}

\section{Appendix 1: Weekly Plan}

\section{WEEKLY PLAN SHEET}

Week $\mathrm{N}^{\circ}$ Date:

Student's name:

\section{Instructions:}

1- Write the correct information under each category presented. The information you write must refer to the present week.

\begin{tabular}{|c|c|c|c|c|}
\hline $\begin{array}{c}\text { Content to } \\
\text { learn this } \\
\text { week }\end{array}$ & $\begin{array}{c}\text { Homework } \\
\text { assigned for } \\
\text { this week }\end{array}$ & $\begin{array}{c}\text { Schedule to do } \\
\text { the homework } \\
\text { assigned }\end{array}$ & $\begin{array}{c}\text { Self-designed } \\
\text { activity aimed } \\
\text { at learning the } \\
\text { content }\end{array}$ & $\begin{array}{c}\text { Schedule to do } \\
\text { the } \\
\text { self-designed } \\
\text { activity }\end{array}$ \\
\hline & & & & \\
\hline
\end{tabular}

2- Write a short reflection assessing your plan for this week. You may use the following questions to guide your reflection.

- How did the different activities help you learn the contents for this week?

- What part of the content, if any, couldn't you learn?

- How difficult or easy was it for you to meet the schedule you set to accomplish the activities? 


\section{Appendix 2: Student Diary}

UNIVERSIDAD DE COSTARICA
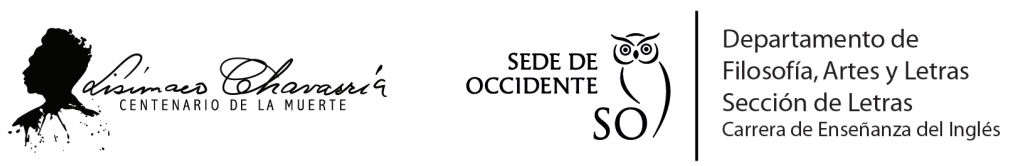

\section{Bachillerato en la Enseñanza del Inglés \\ 10-5309 Fonología del Idioma Inglés \\ Segundo semestre 2013 \\ STUDENT DIARY}

Week $\mathrm{N}^{\circ}$

Date:

Student's name:

\section{Instructions:}

Answer the following questions based on this week's lesson.

1- How did in general you feel about today's lesson? Why did you feel this way?

2- How would you assess your participation in today's lesson?

3- In which two ways has today's lesson contributed to the improvement of your pronunciation?

Instructor's comments: 


\section{Appendix 3: Strategy-Assessment Checklist}

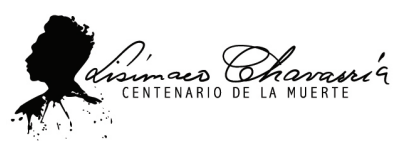

\section{Bachillerato en la Enseñanza del Inglés 10-5309 Fonología del Idioma Inglés Segundo semestre 2013}

Through the past weeks you have been creating weekly plans and a class diary. Assess this experience by responding to the following statements. Mark with an $\mathrm{X}$ the number that best depicts your appraisal of the statement given. Feel free to make any comments you feel necessary. Take the following scale into account:

$$
1=\text { nothing } \quad 2=\text { a little } \quad 3=\text { quite a bit } \quad 4=\text { very much }
$$

\begin{tabular}{|c|c|c|c|c|c|}
\hline Criteria & 1 & 2 & 3 & 4 & Comments \\
\hline \multicolumn{6}{|c|}{ THE WEEKLY PLAN helped me to } \\
\hline \multicolumn{6}{|l|}{ effectively organize my time } \\
\hline \multicolumn{6}{|l|}{ better learn the contents proposed for the week } \\
\hline \multicolumn{6}{|l|}{ take charge of my own responsibilities } \\
\hline \multicolumn{6}{|l|}{ think over my learning actions of the week } \\
\hline \multicolumn{6}{|c|}{ THE STUDENT DIARY helped me to } \\
\hline \multicolumn{6}{|l|}{ become aware of my role as a learner in class } \\
\hline \multicolumn{6}{|l|}{$\begin{array}{l}\text { clearly see how the class contributed to my learn- } \\
\text { ing }\end{array}$} \\
\hline \multicolumn{6}{|c|}{ In general this EXPERIENCE } \\
\hline \multicolumn{6}{|l|}{$\begin{array}{l}\text { motivated me to do more than required to learn } \\
\text { the class contents }\end{array}$} \\
\hline $\begin{array}{l}\text { made me more independent as a learner in this } \\
\text { course }\end{array}$ & & & & & \\
\hline
\end{tabular}

